University of Nebraska - Lincoln

DigitalCommons@University of Nebraska - Lincoln

1983

\title{
Reassessment of the Rates at which Oil from Natural Sources Enters the Marine Environment
}

Keith A. Kvenvolden

U.S. Geological Survey

John W. Harbaugh

Stanford University

Follow this and additional works at: https://digitalcommons.unl.edu/usgsstaffpub

Part of the Earth Sciences Commons

Kvenvolden, Keith A. and Harbaugh, John W., "Reassessment of the Rates at which Oil from Natural Sources Enters the Marine Environment" (1983). USGS Staff -- Published Research. 426.

https://digitalcommons.unl.edu/usgsstaffpub/426

This Article is brought to you for free and open access by the US Geological Survey at DigitalCommons@University of Nebraska - Lincoln. It has been accepted for inclusion in USGS Staff -- Published Research by an authorized administrator of DigitalCommons@University of Nebraska - Lincoln. 


\title{
Reassessment of the Rates at which Oil from Natural Sources Enters the Marine Environment*
}

\author{
Keith A. Kvenvolden \\ US Geological Survey, \\ 345 Middlefield Road, Menlo Park, California 94025, USA \\ $\&$ \\ John W. Harbaugh \\ Department of Applied Earth Sciences, \\ Stanford University, Stanford, California 94305, USA
}

(Received: 3 March, 1983)

\begin{abstract}
Previous estimates of the world-wide input of oil to the marine environment by natural seeps ranged from 0.2 to 6.0 million (metric) tonnes per year with a 'best estimate' of 0.6 million tonnes per year. Based on considerations of the acailability of oil for seepage from the world's known and assumed oil resources, we believe that the world-wide natural oil seepage over geological time should be revised to about 0.2 million tonnes per year with a range upward or downward of a factor of ten leading to estimates between 0.02 and 2 million tonnes per year. Our estimate of the amount of oil eroding from the land and being transported to the oceans is about 0.05 million tonnes per year with an order of magnitude uncertainty. Therefore, while the uncertainties are large, we estimate that the total amount of oil entering the marine environment by natural, geological processes, is about 0.25 million tonnes per year, and the estimate may range from about 0.025 to 2.5 million tonnes per year.
\end{abstract}

*This paper was prepared for the National Academy of Sciences as a contribution to the Petroleum in the Marine Environment/Update Workshop, held November 9-13, 1981, and may not reflect the consensus of workshop participants or the National Academy.

Marine Entiron. Res. 0141-1136/83/\$03.00 C Applied Science Publishers Ltd, England, 1983. Printed in Great Britain 
This rate applies over geological time, but episodic fluctuations in the input of oil to the marine entironment may cause the rate to exceed this range in any one year.

\section{INTRODUCTION}

The US National Academy of Sciences (1975), in response to the need to obtain estimates of the amount of petroleum entering the oceans, prepared a document on the inputs, fates, and effects of petroleum in the marine environment. The Academy's report has served as a major reference on this subject during the past seven years, and contains estimates (summarized in Table 1) of the amount of liquid petroleum that enters the oceans from all known sources. One significant conclusion in the NAS report is that about $90 \%$ of the petroleum entering the marine environment is in the form of pollutants associated with the production, transportation, and utilization of petroleum. The remaining $10^{\circ}$ comes from oil seeps that occur naturally. Landes (1973) has stated that natural oil seeps cause some 'pollution' of the oceans, but such a statement extends the definition of pollution beyond its usually accepted meaning which connotes contamination by man's activities.

Oil seeps are natural phenomena over which man has little direct control, although oil production probably has reduced oil seepage rates and secondary recovery methods using increased formation pressures could possibly cause increased rates of oil seepage. Semantics aside, oil that enters naturally into the marine environment does establish a

TABLE 1

Estimated Annual Input of Petroleum to the Marine Environment (US National Academy of Sciences, 1975)

\begin{tabular}{lcc}
\hline & $\begin{array}{c}\text { Million } \\
\text { metric tonnes/year }\end{array}$ & 0 \\
\hline Marine transportation & $2 \cdot 13$ & 35 \\
Runoff-river and urban & 1.9 & 31 \\
Waste-refinery, industrial and municipal & 0.8 & 13 \\
Atmosphere & 0.6 & 10 \\
Natural seeps & 0.6 & 10 \\
Offshore production & 0.08 & 1 \\
Total & 6.11 & 100
\end{tabular}


'background' against which pollution resulting from man's activities should be measured. This paper reviews information obtained since 1975 and reassesses the estimates of the amount of petroleum entering the marine environment through natural processes.

Petroleum as gas, oil and tar may enter the marine environment directly through seeps or may enter indirectly through erosional processes that carry exposed petroleum to the oceans. Our paper will not consider the gaseous components of petroleum in seepages that affect the marine environment although gas seeps are common in the oceans (for example, see Watkins \& Worzel, 1978) and can be detected acoustically (Tinkle $e t$ al., 1973). Gaseous components are either lost to the atmosphere or are quickly assimilated in the marine environment, and there is usually little visible evidence of their presence. On the other hand, liquid petroleum (oil and tar) seeps have a long-term presence. In this paper we use the term 'oil' to refer collectively to both oil and tar.

If all oil presently entering the oceans came from seeps and erosion, the problem of estimating the annual input of oil into the oceans would be simplified, but the problem is complicated by pollution resulting from man's activities. It is difficult to estimate the background level of oil in the marine environment because much oil supplied through pollution cannot be readily distinguished from oil that enters the oceans naturally.

The occurrence of $\operatorname{tar}$ in the oceans partially illustrates the problem. If only natural processes were involved in its origin, measuring the amount of tar in the oceans could provide a way of estimating natural seepage of oil into the marine environment. But oceanic tar has multiple sources with pollution from oil transportation systems being a prime suspect (Wong $e t$ al., 1973; Butler et al., 1973; Jeffrey et al., 1974; Sleeter et al., 1976; Levy \& Walton, 1976; Shekel \& Ravid, 1977). However, others (Koons \& Monaghan, 1973; Geyer \& Sweet, 1973; Sweet, 1974; Geyer \& Giammona, 1980; Geyer, 1981) argue that, at least for the Gulf of Mexico, the oceanic tar is mostly from natural oil seeps, although the exact locations of most of these seeps are difficult to identify. Ocean tars provide evidence for seeps but they are difficult to use in estimating natural seepage rates. However, historical accounts, summarized by Weaver (1969, pp. 1-8) and Yerkes et al. (1969) for the oil seeps off southern California, and by Geyer \& Giammona (1980) for the Gulf of Mexico, and by Landes (1973) in general, clearly show that oil seeps have been active in the historic past, and that oil entered the marine environment before the petroleum industry existed. 
The estimated input of oil from naturally occurring seeps to the marine environment ranges widely from 0.2 to 6.0 million metric tonnes per year with a 'best estimate' of 0.6 million metric tonnes per year (US National Academy of Sciences, 1975). These figures result from an NAS background report by R. D. Wilson later published by Wilson et al. (1973 and 1974). The estimate given above is now commonly accepted and has been widely cited (Frey, 1977; Bates \& Pearson, 1975; Grossling, 1977: Koons \& Monaghan, 1977; Jeffrey, 1980). The estimate of 0.6 million tonnes per year is about the same as the amount of oil ( 0.5 million tonnes) that escaped during the drilling of the Pemex well Ixtoc I that flowed uncontrolled for about 300 days into the Gulf of Mexico (Patton et al., 1981). The paper by Wilson et al. (1973) is the first estimate of natural seepage rates that incorporates extensive geological considerations.

\section{ESTIMATING NATURAL SEEPAGE RATES}

Wilson et al. (1973) extrapolated the few available seepage rates to obtain an estimate of the world-wide rate of natural seepage of oil into the marine environment. They combined seepage rates on land with information on reported marine seeps and then extrapolated the data to the continental margins which they classified as areas of potentially high, medium and low seepage. They incorporated tectonic history, earthquake activity and sediment thickness in their appraisal. Five basic assumptions were used in their estimates:

1. More seeps exist in offshore basins than have been observed.

2. Factors that determine the total seepage in an area (number of seeps per unit area and the daily rate for each seep) are related to the general geological structural type of the area and to the stage of sedimentary basin evolution.

3. Within each structural type, seepage (numbers of seeps and to a lesser extent, rate per seep) is thought to depend primarily on the area of exposed rock, and not on rock volume. The assumption presumes that there is sufficient sediment volume and organic matter for the maturation and generation of petroleum.

4. Most marine seeps are clustered within the continental margins where the thickness of sediments exceeds a certain minimum.

5. Seepage rates are lognormally distributed. 
Although the geological relationships developed by Wilson et al.(1973) that affect seepage rates are reasonable and seem to accord well with observations, the statistical arguments of the last assumption may be questionable. On purely abstract grounds, an exponential distribution of seepage rates is more likely than a lognormal distribution. While oil-field volumes are generally lognormally distributed, the actual volumes of all oil accumulations (most of which are perhaps too small to be produced, and thereby cannot be classified as 'fields') are likely to have an exponential distribution (Harbaugh \& Ducastaing, 1981). The volumes of natural seepages are probably statistically distributed in a manner similar to the volumes of oil accumulations in general, because seeps do not necessarily need sources as large as oil fields. Considering the difficulties encompassed in the other assumptions, however, the form of the frequency distribution may be a minor matter.

While a quantitative estimate of seepage rates is highly desirable, data presently available on the geographical distribution of natural seeps, and on actual seepage rates, are not adequate. For example, the seepage flow rates for individual seeps as listed by Wilson et al. (1973) are highly suspect as to their accuracy. Apparently, most estimates attached to individual seeps are rough visual estimates, and most are probably in substantial error. In addition, there has been no systematic sampling to detect small or intermediate size seeps in areas where more prominent seeps exist. Thus, the volume of these smaller seeps is essentially unrecorded. It is possible that small, and presumably much more numerous, seeps have contributed a significant volume to the total quantity of oil released by seeps.

Since Wilson et al. (1973) first made their estimate, little new information has become available that would change their world-wide estimates of marine seepage rates. Their compilation of 190 reported marine seep areas (Fig. 1) was derived mostly from Johnson (1971) and Landes (1973), and their list can be modified by only six reports of seeps in the following locations: Scott Inlet, Canada; Buchan Gulf, Canada; Australian north coast; Laguna de Tamiahua, Mexico; Venezuelan shelf; and the Gulf of Alaska. The two seeps in Canada are offshore of Baffin Island; both visual and chemical evidence indicates submarine seepage of oil in Scott Inlet (Levy, 1978) and in Buchan Gulf (Levy \& Ehrhardt, 1981). Bitumen on both the north and south coasts of Australia was attributed to natural seeps (McKirdy \& Horvath, 1976); however, seep areas on the south coast had been identified previously (Wilson et al., 


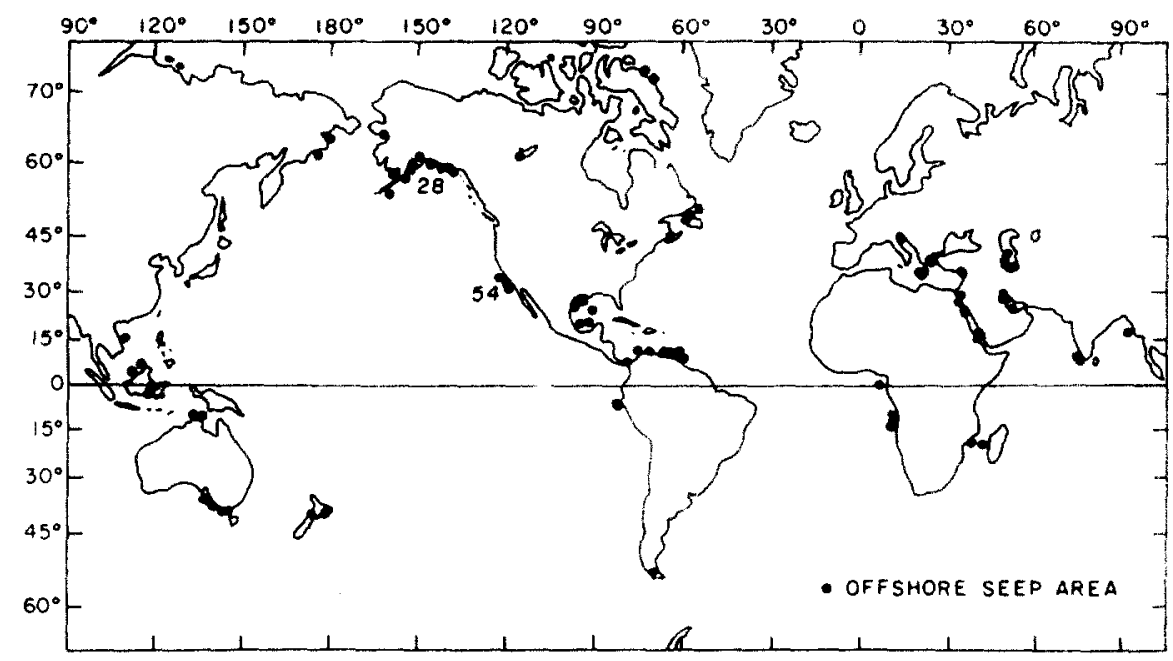

Fig. 1. Location of reported, naturally occurring, submarine oil seeps. Map was adapted from Wilson et al. (1973). The numbers 28 and 54 refer to the number of seeps in the area.

1973). Seismic profiling provided evidence for an oil seep in the Laguna de Tamiahua in the Gulf of Mexico (Geyer \& Giammona, 1980; Giammona, 1980). A large seep on the Venezuelan shelf was indicated by hydrocarbon analyses of seawater samples (Harvey et al., 1979); that natural seeps occur on the Venezuelan shelf had been noted previously however (Wilson et al., 1973). Blasko (1976) gave additional information on 18 oil and 7 tar seep areas in the Gulf of Alaska that had been listed earlier by Wilson et al. (1973). These seeps are along the Alaskan coast and contribute oil to the ocean via streams (Rosenberg, 1972).

Of the six reports on marine seeps published since 1973, only a report by Harvey et al. (1979) estimates the amount of oil present, and none of the reports provide estimates of rates of seepage. Harvey et al. (1979) found oil below the sea surface at $200 \mathrm{~m}$ depth during a ship's traverse over a distance of 800 nautical miles off the north-east coast of South America. They suggested that the oil had seeped from the Venezuelan shelf. The amount of submerged oil was estimated to be more than one million tonnes. Such a large amount of oil implies a rate of seepage that would raise estimates of world-wide natural seepage rates in a given year, but such a rate is probably not applicable to estimates of seepage rates over geological time.

Accurate determinations of seepage rates of submarine seeps are 
TABLE 2

Rates of Oil Seepage Offshore of Southern California

\begin{tabular}{lcl}
\hline & Barrels per day & \multicolumn{1}{c}{ Reference } \\
\hline Coal Oil Point & $50-70$ & Allen et al., 1970 \\
Coal Oil Point & $10-100$ & Mikolaj et al., 1972 \\
Coal Oil Point & $11-160$ & Wilkinson, 1971 \\
Coal Oil Point & $900[90]^{a}$ & Straughan \& Abbott, 1971 \\
Santa Monica Bay & $2-20$ & Mikolaj et al., 1972 \\
Santa Monica Bay & $12-15$ & Wilkinson, 1971 \\
Santa Barbara Channel & $40-670$ & Fischer, 1978 \\
\hline
\end{tabular}

${ }^{a}$ See text.

difficult to achieve because direct measurements must be made under water, and for many seeps the rate of flow is intermittent. Although submarine oil seeps occur world-wide, rates of seepage have only been measured in the offshore area of southern California. Measuring techniques in general have been primitive and involve extensive extrapolation (Allen et al., 1970). In many cases oil was collected in submerged jars, and the amount of oil collected in hours or a few days was then extrapolated to the amount seeping from the seafloor in a year. Also used were surface methods wherein the thickness, width, and drift of surface slicks were measured in order to calculate indirectly oil seepage rates. The accuracy of the measurements is questionable considering the problems involved in acquiring the data.

Estimations of rates of seepage offshore of southern California have not changed significantly since Wilson et al. (1973) made their report (Table 2). The estimates available to them for Coal Oil Point and Santa Monica Bay ranged from 13 to 900 barrels per day. The more recent estimate of Fischer (1978), based on mapping of the geographical trends of seeps, ranged from 40 to 670 barrels per day, a span of values not greatly different from the earlier estimates. However, the 900 barrels per day estimate published by Straughan \& Abbott (1971) is a printing error and should have read 90 barrels per day (Straughan, written communication, 1982).

The world-wide estimate by Wilson et al. (1973) of annual marine seepage of oil depends in part on the measured seepage rates from offshore of southern California. The estimated range of these seepage rates has not changed significantly during the past seven years. Likewise, 
the number of identified seep areas throughout the world is not significantly larger. We conclude, based on this information and our skepticism about the accuracy of measured seepage rates, that any change to be made in the current estimate of world-wide seepage rates will depend on factors other than our present knowledge based on direct measurements of seeps and seepage rates. Thus, we take an approach different from Wilson et al. (1973). Our results, therefore, do not come from refinements of their methods, but rather are based instead on assumptions regarding the amount of oil available for seepage.

\section{GEOLOGICAL IMPLICATIONS OF SEEPAGE RATES}

The average rate of natural seepage of oil into the marine environment calculated over geological time, ultimately depends on the amount of oil available for seepage, which in turn is related to world-wide petroleum resources. Estimates of these resources range widely, as shown in Table 3, where several categories of petroleum are listed. A comparison can be made between estimated oil seepage rates and the amount of oil available for seepage in order to assess the maximum geological time that the seepage rates could be sustained. Table 4 illustrates this comparison. A range of assumed seepage rates is given that includes the estimates of Wilson et al. (1973) of 0.2 to 6 million tonnes per year, but the range is extended downward to 0.02 million tonnes per year and upward to 10 million tonnes per year. The amounts of oil available for seepage also extend over a very wide range. At the low end, 10 thousand million tonnes is near the value of 14 thousand million tonnes of the world's total proven oil reserves and potential resources offshore as estimated by Albers et al. (1973). The value of 30000 thousand million tonnes comes from Wilson $e t$ al. (1973) who accepted an estimate of 300 thousand million tonnes of oil instead. Because this amount of oil may represent only $1 \%$ of the oil mobilized from source beds, they assumed that the amount of oil available for seepage may be as much as 30000 thousand million tonnes, a value we believe is probably too large. We question the assumption that $99 \%$ of oil mobilized from source beds is available for seepage, on the grounds that knowledge of primary migration and of the state of oil undergoing primary migration is too poorly understood (Roberts \& Cordell, 1980) to permit such an assumption to be made. Nevertheless, we have not only included 30000 thousand million tonnes, but have 
Rates of oil input into the marine environment

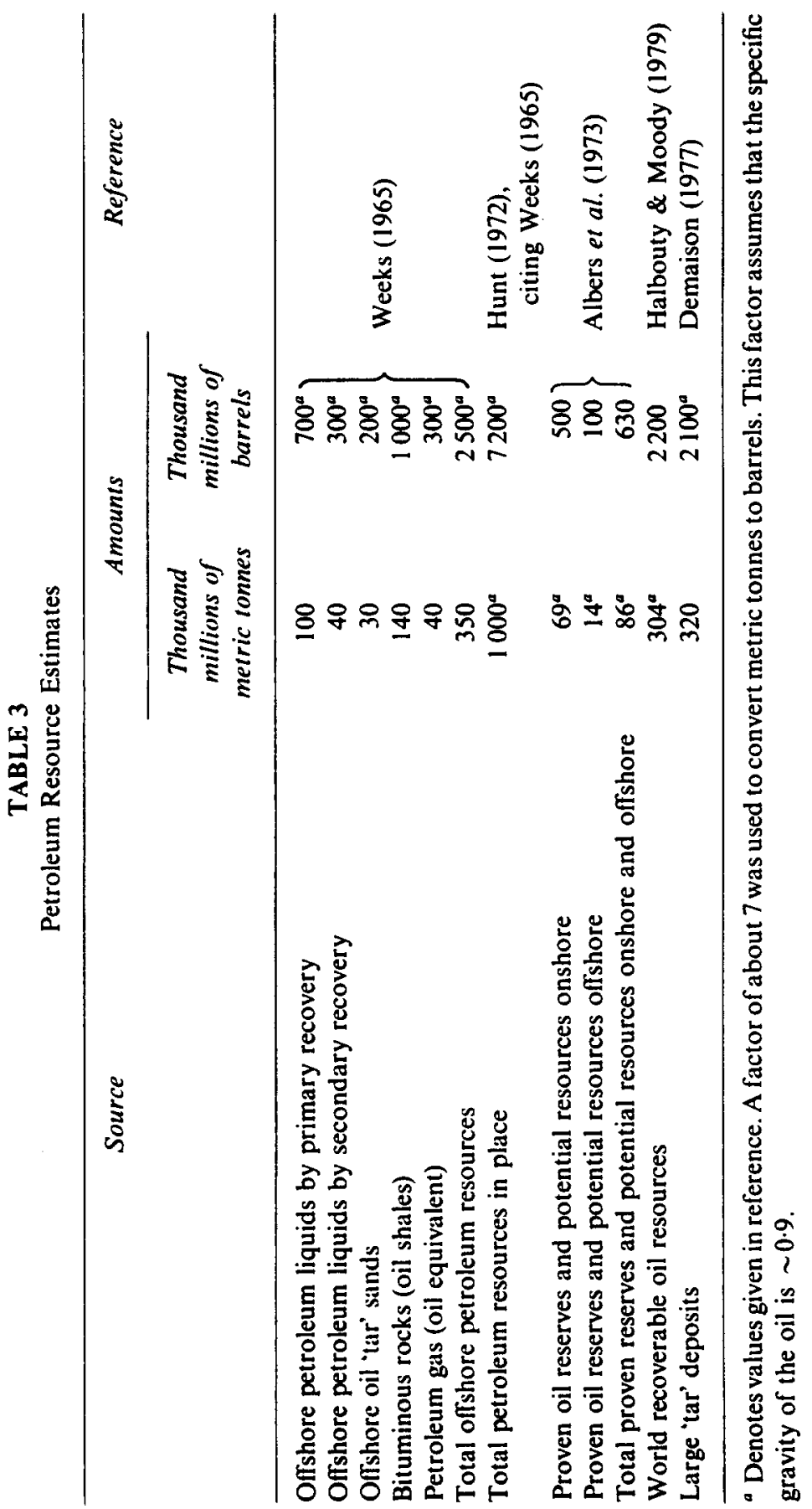




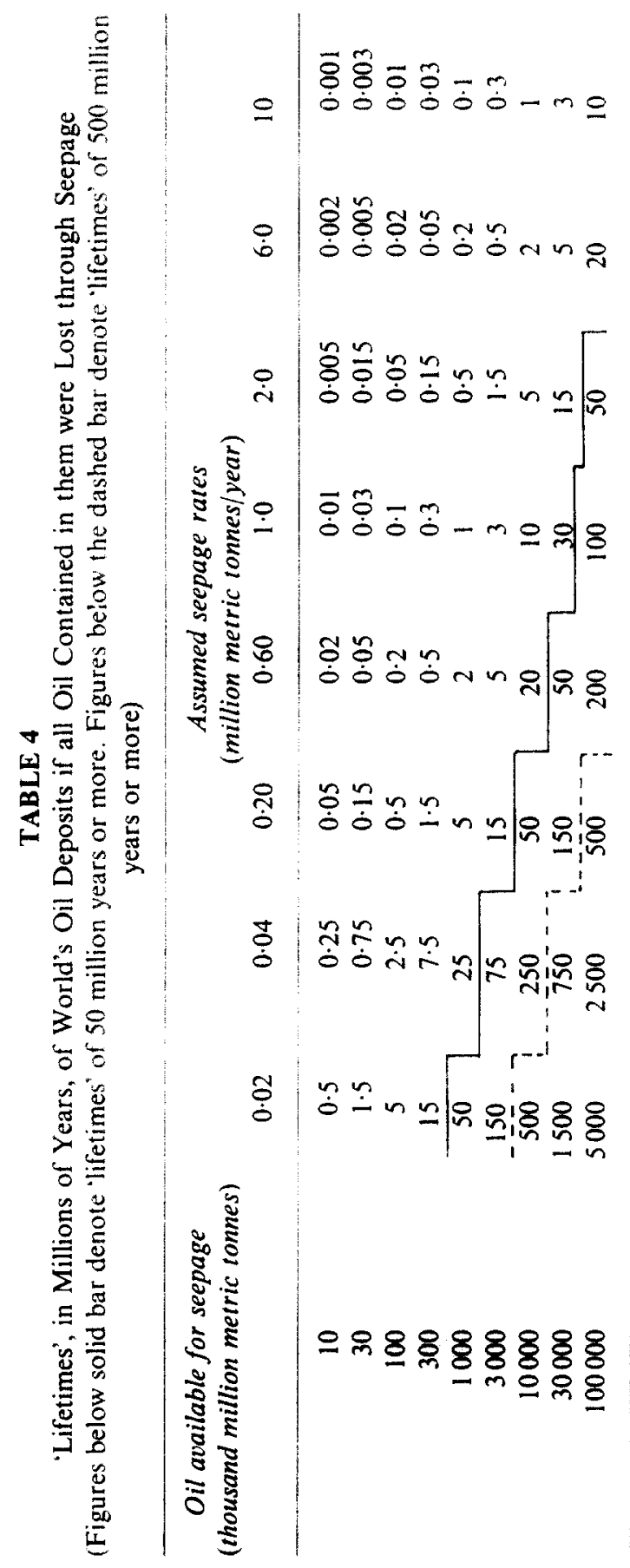


expanded the scale to oil available for seepage to 100000 thousand million tonnes to attempt to include all unknowns with regard to the amount of oil that would have been available for seepage from reservoir and source rocks during geological time and that will become available in the future during the lifetimes of the seepages.

Assumptions concerning world-wide oil seepage rates and the total quantity of oil available for seepage are closely interdependent. The figures for 'lifetimes' of the total quantity of oil available for seepage, listed within the body of Table 4, illustrate this interdependence. If we set 50 million years as the minimum acceptance estimate of 'lifetimes', then the oil available for seepage must range from 1000 to 100000 thousand million tonnes. Correspondingly the seepage rates must range between 0.02 and 2 million tonnes per year. All 'lifetime' values below the solid, stair-step bar in Table 4 satisfy these conditions. If we assume a 'lifetime' that is an order of magnitude greater (at least $\mathbf{5 0 0}$ million years) the seepage rates are necessarily much lower and the minimum amount of oil available for seepage must be higher as shown in the figures below the dashed, stair-step bar of Table 4.

Therefore, to maintain oil seepage for a span of geological time of 50 million years (most of the Tertiary period) requires that seepage rates be equal to or less than 2 million tonnes per year. At the same time the amount of oil available for seepage must be equal to or greater than 1000 thousand million tonnes. If seepage is maintained for 500 million years (most of the Phanerozoic period) then seepage rates must be equal to or less than 0.02 million tonnes per year, and the amount of oil available for seepage must be equal to or greater than 10000 thousand million tonnes. The oil seepage rate that best seems to accommodate the requirements of reasonable geological time and reasonable assumptions concerning availability of oil for seepage is 0.2 million tonnes per year with an uncertainty both upward and downward of an order of magnitude. Thus we reach the conclusion that the average rate of oil seepage over time ranges from 0.02 to 2.0 million tonnes per year with a 'best estimate' of 0.2 million tonnes per year. This value is a factor of three lower than the 'best estimate' of Wilson et al. (1973) of 0.6 million tonnes per year.

The estimate of any specific seepage rate, including our 'best estimate' of 0.2 million tonnes per year, is relevant only over geological time. In any particular year natural seepage events can be different from this estimate by perhaps orders of magnitude. For example, the presumed submarine seep, estimated to contain one million tonnes of submerged oil from the 
Venezuelan shelf, was accidently discovered in the south-west North Atlantic Ocean in the winter of 1978 (Harvey et al., 1979). The rate of seepage of this event is unknown, but the uncertainties of global seepage rates discussed above require that such a massive seep be an episodic and not a sustained event in geological time.

\section{EFFECTS OF NATURAL SEEPS}

Although oil seeps in the marine environment are common and the areas of potential seepage are widespread geographically, the current environmental effect of these seeps is small. For example, at Coal Oil Point, California, hydrocarbons are not being concentrated either in the water or in the sediments, except very close to the seeps (Koons \& Brandon, 1975). Tar from natural seeps is a nuisance on beaches, but Indians formerly used tar and oil from natural seeps along the coast of southern California (Weaver, 1969, p. 2) and along the coast of Texas (Geyer \& Giammona, 1980). Whether oil and tar on beaches is good or bad depends on one's perspective.

The effect of natural oil seeps in the past should be diminished in the future because the production of oil from many of the reservoirs that have ultimately supplied the seeps will reduce the amount of oil available for seepage. Link (1952) emphasized the relationship between surface seeps of oil and gas and the occurrence of petroleum in reservoirs. Many great oil fields have been discovered because of natural seeps. Oil seeps in Lake Maracaibo (Landes, 1973) have decreased since oil production began there. Diminishing seepage rates in the Santa Barbara Basin, offshore of California, have also been noted by Fischer \& Stevenson (1973), where declining seep activity is directly related to the production of hydrocarbons. A seep on Trinidad Island in the Caribbean Sea consisted of a stream of tar 15 to 18 feet deep that constantly flowed into the sea before asphalt mining operations dropped the level of Trinidad Asphalt Lake (Landes, 1973). Thus, this large natural seep nolonger contributes tar directly to the marine environment. These examples seem to document the assertion that continued production of petroleum should cause seepage rates to decrease in the future. However, those seepages that are unrelated to commercial oil fields would not be affected.

Studies of biological activity associated with an oil seep in the Santa Barbara Channel (Spies \& Davis, 1979; Davis \& Spies, 1980) show that 
there is a well-developed community of bottom-dwelling marine organisms in the sediments associated with the seep. Comparison of benthic fauna at the oil seep with fauna at an area free of seepage showed that the organism communities are the same. At the oil seep there were higher densities of individual organisms in many populations, but there were no dramatic differences in diversity of the populations.

\section{CHEMICAL AND PHYSICAL CHARACTERIZATION OF OIL}

Oil entering the marine environment comes from various sources (Table 1); identification of these sources is needed to understand the relative importance of each source. Identification is difficult or impossible when an attempt is made to distinguish oil that has been spilled from oil that has seeped from the same reservoir. The only difference is the manner in which the oil reached the surface. Unless the oil that has been spilled has chemical and physical properties that permit it to be distinguished from seepage oil, segregation of sources cannot be made effectively. Eastwood \& Grant (1976) claim, on the basis of infrared measurements, that natural seepage oil can be distinguished from spills at offshore platforms, but differences between seeped and spilled oils persisted for only a week after exposure to weathering:

Kaplan \& Reed (1977) and Reed \& Kaplan (1977) applied various chemical techniques to analyzed marine petroleum seeps. Procedures included gas chromatography and gas chromatography/mass spectrometry of extracted hydrocarbons and isotope mass spectrometry of carbon, nitrogen, and sulfur in gas and oil. The content of nitrogen and sulfur, their isotopic ratios, the carbon isotopic composition of chromatographic fractions, and the chemical composition of cycloalkanes distinguish produced oils from seepage oils derived from different geological formations. Marine sediments receiving petroleum ccntributions can be differentiated from those in which only biogenic hydrocarbons are present. Triterpenoid hydrocarbons were also used for this differentiation (Simoneit \& Kaplan, 1980). Distinction could not be made, however, between seep and spilled oil from the same source. Thus, in most situations it is difficult to ascertain whether tar on a beach results from natural seepage or pollution.

Remote sensing using Landsat digital contrast-stretch enhancement (Deutsch \& Estes, 1980), and ultraviolet and thermal infrared scanners 
(Eyer et al., 1977) have been employed with marginal success to map the distribution of oil seeps. Such methods cannot readily distinguish between oil seeps and oil spills. Natural oil 'slicks', such as the copepod 'slick' in the north-west Pacific Ocean described by Lee \& Williams (1974), could be confused with an oil seep by remote sensing methods.

\section{EROSIONAL INPUTS OF OIL INTO THE OCEANS}

The amount of oil that enters the marine environment by erosional processes has not been estimated before. Previous work by Wilson et al. (1973) considers the marine input of oil only from natural seeps. Any estimation of erosional input of oil into the oceans can only be uncertainly approximated. Giger et al. (1980) suggest that hydrocarbons found in postglacial mud samples in Greifensee, Switzerland, were derived by erosion of ancient sedimentary rocks outcropping in the catchment basin of the lake, but no estimation was given of the total amount of hydrocarbons derived by erosion. Meyers et al. (1980) mentioned erosion of ancient sediment as one source of hydrocarbons in Lake Huron, but they made no estimate of the amount of hydrocarbons from this source. Although these papers consider the problem of erosional input of hydrocarbons, they do not provide the kinds of measures needed to make estimates of this process.

Two places where the erosional input of oil into the oceans could be studied in detail are along the coast of southern California and along the Dorset coast of England. Weaver (1969, pp. 1-8) shows examples of oil seeps at the beach and in the sea cliffs facing the Santa Barbara Channel where erosion presently is taking place. The Marine Pollution Subcommittee of the British National Committee on Oceanic Research (1980) identified the Dorset coast of southern England, where oil source rocks as well as oil-containing reservoir rocks were exposed. They suggest this area as one for the study of natural seeps and erosional processes affecting the distribution of oil in the marine environment. Because no direct information is available on erosional inputs of oil to the oceans, an indirect approach can be taken. This approach assumes that a portion of the organic carbon transported by all rivers is petroleum. Estimates of the organic carbon content of rivers vary by nearly two orders of magnitude, from 30 to 1000 million tonnes per year, as summarized by Schlesinger $\&$ 
Melack (1981). They concluded, based on two approaches, that the amount of organic carbon transported by rivers is 370 or 410 million tonnes per year. Independently, Meybeck (1981) reached a similar estimate of $\mathbf{4 0 0}$ million tonnes per year.

In estimations of the organic carbon content of rivers, no distinction has been made between carbon from modern biological sources, carbon from pollution and ancient carbon indigenous to the eroded sediment being carried by the rivers. This latter class of carbon is of interest in estimating the erosion input of oil to the oceans. The total organic content of rivers is divided about equally between dissolved organic carbon and particulate organic carbon (Meybeck, 1981). We assume that the ancient organic carbon in rivers is present as a portion of the particulate organic carbon. Meybeck (1981) estimates that the amount of particulate organic carbon in rivers is 179 million tonnes per year. About half of this, or 88 million tonnes per year, is ancient organic carbon. This number results from assuming that the organic carbon content of eroded sediment particles is the same as the average organic content of sedimentary rocks, which is $0.5 \%$ according to Ronov (1976). Because the total particulate load of rivers is 17500 million tonnes per year (Meybeck, 1981), the amount of ancient organic carbon in these particles is thus estimated to be about 88 million tonnes. Organic carbon is commonly assumed to be $50 \%$ of organic matter (Meybeck, 1981). Therefore, a rough estimate of the amount of ancient organic matter in eroded sediments is approximately 176 million tonnes per year.

In ancient sedimentary rocks the amount of extractable organic matter constitutes, on the average, about $6 \%$ of the total organic matter (Hunt, 1979 , p. 264). An assumption is made here that the same proportion of organic matter is extractable from the particulate organic matter in sediment particles in the rivers as is extractable from the carbon in rocks being eroded by the rivers. Thus the amount of extractable organic matter in sediment particles in rivers is about 10.6 million tonnes per year. Most of the extractable organic material is dispersed in sedimentary rocks, but $0.5 \%$ of this material is petroleum (Hunt, 1972). If this factor is applied to the extractable organic matter of sediment particles in rivers, then the amount of oil transported from eroding outcrops by rivers to oceans is about 0.05 million tonnes per year. This estimate is probably high. Losses of organic carbon by oxidation during river transport and by sedimentation in estuaries leading to the oceans were not considered because of lack of data on these processes. Because of the numerous assumptions used to 
obtain our estimate, there is an uncertainty of at least plus or minus an order of magnitude.

In estimating rates of seepage of oil into the marine environment, we can compare these rates against the amount of oil assumed to be available for seepage over geological time (Table 4). This same oil would be available for erosional processes over geological time. The amount of oil available is sufficient to sustain the estimated rates of natural seepage as well as rates of erosion of oil for a period of time equivalent to the Tertiary period and probably longer.

\section{CONCLUSIONS}

Estimation of the amount of petroleum that naturally enters the marine environment requires a number of assumptions, each of which has large uncertainties. Two processes are involved. Oil reaches the oceans directly through natural seeps and indirectly through erosion. Wilson et al. (1973) made assumptions, based on geological structural types, earthquake activity, and sediment thickness, to classify the seepage potential of continental margins. With this information, along with locations of known seeps and a few seepage rates, they estimated that oil seeps into the oceans at rates ranging from 0.2 to 6.0 million tonnes per year with the 'best estimate' of 0.6 million tonnes per year. Their estimate used seepage flow rates which have large uncertainties because there are few, if any, sufficiently accurate determinations of seep rates measured over significant time periods. This lack of accurately measured seep rates limits the accuracy of any extrapolation to world-wide seep rates. Since Wilson et al. (1973) made their estimates, no new information has been presented that greatly alters their estimates.

In reassessing the estimates of natural seepage of oil in the marine environment we concluded that any change in the current estimates will depend on factors other than the present knowledge of locations and volumes of seeps and of seepage rates. Therefore, we have compared a range of oil seepage rates with a range of the amount of oil presumed available for seepage: This comparison leads to the conclusion that a 'best estimate' for natural oil seepage is about 0.2 million tonnes per year with an uncertainty upward and downward of an order of magnitude. This estimate best accommodates requirements for reasonable geological time 
TABLE 5

Summary of Estimates of Rates of Oil Entering the Marine Environment (million tonnes per year)

\begin{tabular}{lcccc}
\hline Estimate & \multicolumn{2}{c}{$\begin{array}{c}\text { Natural oil seepage } \\
\text { (Wilson et al., 1973) }\end{array}$} & $\begin{array}{c}\text { Eroded oil } \\
\text { (This paper) }\end{array}$ & $\begin{array}{c}\text { Total oil } \\
\text { (This paper) }\end{array}$ \\
\hline Low & 0.2 & 0.02 & 0.005 & 0.025 \\
Intermediate & 0.6 & 0.2 & 0.05 & 0.25 \\
High & 6 & 2 & 0.5 & 2.5 \\
\hline
\end{tabular}

for seepage to take place and for reasonable assumptions concerning the availability of oil for seepage.

To the estimate of submarine oil seepage rates we added an estimate of the amount of oil that is eroded from continents. Based on the organic carbon content of sediments in rivers we calculated that about 0.05 million tonnes per year of oil is eroded and transported to the oceans. This estimate also has an uncertainty of at least plus or minus an order of magnitude.

Our reassessment of the natural inputs of oil into the marine environment in millions of metric tonnes per year is summarized in Table 5. Therefore, the total input of oil into the marine environment is estimated to range from 0.025 to 2.5 million tonnes per year with a 'best estimate' of about 0.25 million tonnes per year. This estimate is relevant only over geological time, and in any given short interval of time natural inputs of oil into the oceans may differ significantly from this estimate. The amount of oil available for seepage and erosion is sufficient to sustain these processes for a period of time equal to the Tertiary and possibly longer.

\section{ACKNOWLEDGEMENTS}

We thank C. B. Koon, J. W. Farrington, and W. S. Sackett for providing preliminary information on this subject. We also thank G. R. Harvey and R. A. Geyer for critical comments and discussion. We greatly appreciate the efforts of N. L. Blair who ran computer searches of GeoRef, Tulsa Abstracts, Oceanic Abstracts, Pollution Abstracts, and GeoArchive. We are especially grateful to $\mathrm{W}$. Sanders who worked closely with us to obtain most of the references used for this review. 


\section{REFERENCES}

Albers, J. P., Carter, M. D., Clark, A. L., Coury, O. B. \& Schweinfurth, S. P. (1973). Summary petroleum and selected mineral statistics for 120 countries, including offshore areas. US Geological Survey Prof. Paper $817.149 \mathrm{pp}$.

Allen, A. A., Schlueter, R. S. \& Mikolaj, P. G. (1970). Natural oil seepage off Coal Oil Point, Santa Barbara, California. Science, 170, 974-7.

Bates, C. C. \& Pearson, E. (1975). Influx of petroleum hydrocarbons onto the ocean. 7th Offshore Technology Conference, OTC 2390, pp. 535-44.

Blasko, D. P. (1976). Occurrences of oil and gas seeps along the Gulf of Alaska. 8th Offshore Technology Conference, OTC 2444, pp. 211-20.

Butler, J. N., Morris, B. F. \& Sass, J. (1973). Pelagic tar from Bermuda and the Sargasso Sea. Bermuda Biological Station for Research, Sp. Publ., 10, $346 \mathrm{pp}$.

Davis, P. H. \& Spies, R. B. (1980). Infaunal benthos of a natural petroleum seep: study of community structure. Martine Biology, 59, 31-41.

Demaison, G. J. (1977). Tar sands and supergiant oil fields. Am. Assoc. Petroleum Geologists Bull., 61, 1950-61.

Deutsch, M. \& Estes, J. E. (1980). Landsat detection of oil from natural seeps. Photogrammetric Engineering and Remote Sensing, 46, 1313-22.

Eastwood, D. \& Grant, D. F. (1976). Field infrared method to discriminate natural seeps from non-seeps (Santa Barbara, California area). US Coast Guard, Dept. of Transportation, Rep. No. CG-D-12-77, 18 pp.

Eyer, J. A., Foreman, J. E. \& Raney, G. L. (1977). Natural oil seep detection in marine environments. 9th Offshore Technology Conference, OTC 2765, pp. 325-30.

Fischer, P. J. (1978). Natural gas and oil seeps, Santa Barbara Basin, California. In The State Lands Comm. 1977, California gas, oil, and tar seeps, pp. 1-62.

Fischer, P. J. \& Stevenson, A. J. (1973). Natural hydrocarbon seeps along the northern shelf of the Santa Barbara basin, California. 5th Offshore Technology Conference, OTC 1738, pp. I-159 to I-168.

Frey, M. G. (1977). Oil in marine water.s. 9 th Offshore Technology Conference, OTC 2752, pp. 227-30.

Geyer, R. A. (1981). Naturally occurring hydrocarbons in the Gulf of Mexico and the Caribbean. Proc. Oil Spill Conf., Am. Petroleum Institute, Washington, DC, pp. 445-51.

Geyer, R. A. \& Giammona, C. P. (1980). Naturally occurring hydrocarbons in the Gulf of Mexico and Caribbean Sea. In Marine environmental pollution, Vol. 1, Elsevier Oceanography Series, 27A (Geyer, R. A. (Ed.)). Amsterdam, Elsevier, pp. 37-106.

Geyer, R. A. \& Sweet, W. M., Jr. (1973). Natural hydrocarbon seepage in the Gulf of Mexico. Trans. Gulf Coast Assoc. Geological Societies, 23, $158-69$.

Giammona, C. P. (1980). Biota near natural marine hydrocarbon seep in the western Gulf of Mexico. In Marine environmental pollution, Vol. 1, Elsevier Oceanography Series, 27A (Geyer, R.A. (Ed.)). Amsterdam, Elsevier, pp. 207-28. 
Giger, W., Schaffner, C. \& Wakeham, S. G. (1980). Aliphatic and olefinic hydrocarbons in recent sediments of Griefensee, Switzerland. Geochim. Cosmochim. Acta, 44, 119-29.

Grossling, B. F. (1977). An estimate of the amounts of oil entering the oceans: sources, effects, and sinks of hydrocarbons in the aquatic environment. Proc. of Symp., The Am. Inst. Biological Sciences, pp. 5-36.

Halbouty, M. T. \& Moody, J. D. (1979). World ultimate reserves of crude oil. Tenth World Petroleum Congress, Vo. 2, pp. 291-301.

Harbaugh, J. W. \& Ducastaing, M. (1981). Historical changes in oil-field populations as a method of forecasting field sizes of undiscovered populations: a comparison of Kansas, Wyoming and California. Subsurface Geology Series 5, Kansas Geological Survey, $56 \mathrm{pp}$.

Harvey, G. R., Requejo, A. G., McGillivary, P. A. \& Tokar, J. M. (1979). Observation of a subsurface oil-rich layer in the open-ocean. Science, 205, 999-1001.

Hunt, J. M. (1972). Distribution of carbon in crust of earth. Am. Assoc. Petroleum Geologists, 56, 2273-7.

Hunt, J. M. (1979). Petroleum Geochemistry and Geology. San Francisco, W. H. Freeman and Sons, $617 \mathrm{pp}$.

Jeffrey, L. M. (1980). Petroleum residue in the marine environment: In Marine environmental pollution, Vol. 1, Elsevier Oceanographic Series, 27A (Geyer, R.A. (Ed.)). Amsterdam, Elsevier, pp. 163-79.

Jeffrey, L. M., Pequegnat, W. E., Kennedy, E. A., Vos, A. \& James, B. M. (1974). Pelagic tar in the Gulf of Mexico and Caribbean Sea. In Marine pollution monitoring (petroleum). NBS Spec. Publ. 409, pp. 233-5.

Johnson, T. C. (1971). Natural oil seeps in or near the marine entironment: $a$ literature survey. US Coast Guard Rept. Proj. No. 714141/002, 30 pp.

Kaplan, I. R. \& Reed, W. E. (1977). Chemistry of marine petroleum seeps in relation to exploration and pollution. 9th Offshore Technology Conference, OTC 2933, pp. 425-34.

Koons, C. B. \& Brandon, D. E. (1975). Hydrocarbons in water and sediment samples from Coal Oil Point area, offshore California. 7th Offshore Technology Conference, OTC 2387, pp. 513-21.

Koons, C. B. \& Monaghan, P. H. (1973). Petroleum-derived hydrocarbons in Gulf of Mexico waters. Trans. Gulf Coast Assoc. Geological Societies, 23, 170-81.

Koons, C. B. \& Monaghan, P. H. (1977). Input of hydrocarbons from seeps and recent biogenic sources: Sources, effects, and sinks of hydrocarbons in the aquatic environment. Proc. of Symp., The Am. Inst. Biological Sciences, pp. 94-107.

Landes, K. K. (1973). Mother nature as an oil polluter. Am. Assoc. Petroleum Geologists, 57, 637-41.

Lee, R. F. \& Williams, P. M. (1974). Copepod 'slick' in the northwest Pacific Ocean. Naturwissenschaften, 61, 505-6.

Levy, E. M. (1978). Visual and chemical evidence for a natural seep at Scout Inlet, Baffin Island District of Franklin. Current Research Part B, Geological survey of Canada, Paper 78-1B, pp. 21-5. 
Levy, E. M. \& Erhardt, M. (1981). Natural seepage of petroleum at Buchan Gulf, Baffin Island. Marine Chemistry, 10, 355-64.

Levy, E. M. \& Walton, A. (1976). High seas oil pollution: particulate petroleum residues in the North Atlantic. Jour. Fisheries Research Board Canada, 33, $2781-91$.

Link, W. K. (1952). Significance of oil and gas seeps in world oil exploration. Am. Assoc. Petroleum Geologists Bull., 36, $1505-40$.

Marine Pollution Subcommittee of the British National Committee on Oceanic Research (1980). The effects of oil pollution: some research needs. Prepared by the above, ISBN 085403 1561, The Royal Society, 6 Carlton House Terrace, London SWIY SAG, England, pp. 78-83.

McKirdy, D. M. \& Horvath, Z. (1976). Geochemistry and significance of coastal bitumen from southern and northern Australia. APEA Journal, 123-35.

Meybeck, M. (1981). River transport of organic carbon to the oceans. In Flux of organic carbon by rivers to the oceans. Carbon Dioxide Effects Research and Assessment Program, 016, CONF 8009140, US Dept. of Energy, Office of Energy Research, Washington, DC, pp. 219-69.

Meyers, P. A., Takeuchi, N. \& Robbins, J. A. (1980). Petroleum hydrocarbons in sediments of Saginaw Bay, Lake Huron. Jour. Great Lakes Research, 6 , $315-20$.

Mikolaj, P. G., Allen, A. A. \& Schlueter, R. S. (1972). Investigation of the nature, extent, and fate of natural oil seepage off southern Califormia. 4th Offshore Technology Conference, OTC 1549, pp. I-367 to I-380.

Mulholland, P. J. (1981). Deposition of riverborne organic carbon in floodplains, wetlands, and deltas. In Flux of organic carbon by ricers to the oceans. Carbon Dioxide Effects Research and Assessment Program, 016, CONF 8009140, US Dept. of Energy, Office of Energy Research, Washington, DC, pp. 142-72.

Patton, J. S., Rigler, M. W., Boehm, P. D. \& Fiest, D. L. (1981). Ixtoc I oil spill: flaking of surface mousse in the Gulf of Mexico. Nature, 290, 235-8.

Reed, W. E. \& Kaplan, I. R. (1977). The chemistry of marine petroleum seeps. Jour. Geochemical Exploration, 7, 255-93.

Roberts, W. H. \& Cordell, R. J. (1980). Problems of petroleum migration. A.APG Studies in Geology No. 10. American Assoc. of Petroleum Geol., Tulsa, $273 \mathrm{pp}$.

Ronov, A. B. (1976). Global carbon geochemistry, volcanism, carbonate accumulation, and life. Geochem. Int., 13, 172-95.

Rosenberg, D. H. (1972). Oil and gas seeps of the northern Gulf of Alaska. In: $A$ review of the oceanography and renewable resources of the northern Gulf of Alaska (Rosenberg, D. H. (Ed.)). Alaska Univ. Inst. Mar. Sci. Rep. No. R7223, Sec. 6, pp. 143-8.

Schlesinger, W. H. \& Melack, J. M. (1981). Transport of organic carbon in the world's rivers. Tellus, 33, 172-87.

Shekel, Y. \& Ravid, R. (1977). Sources of tar pollution on Israeli Mediterranean coast. Environmental Science and Technology, 11, 502-5.

Simoneit, B. R. T. \& Kaplan, I. R. (1980). Triterpenoids as molecular indicators 
of paleoseepage in recent sediments of the southern California Bight. Marine Environmental Research, 3, 113-28.

Sleeter, T. D., Morris, B. F. \& Butler, J. N. (1976). Pelagic tar in the Caribbean and equatorial Atlantic, 1974. Deep Sea Research, 23, 467-74.

Spies, R. B. \& Davis, P. H. (1979). The infaunal benthos of a natural oil seep in the Santa Barbara Channel. Marine Biology, 50, 227-37.

Straughan, D. \& Abbott, B. C. (1971). The Santa Barbara oil spill: ecological changes and natural oil leaks. In: Water pollution by oil (Hepple, P. (Ed.)). Institute of Petroleum, London, pp. 257-62.

Sweet, W. E., Jr. (1974). Tar balls in the sea: a new concept. 6th Offshore Technology Conference, OTC 2002, pp.651-7.

Tinkle, A. R., Antoine, J. W. \& Kuzela, R. (1973). Detecting natural gas seeps at sea. Ocean Industry, 8, 139-42.

US National Academy of Sciences (1975). Petroleum in the marine entironment. National Academy of Sciences, Washington, DC, $107 \mathrm{pp}$.

Watkins, J. S. \& Worzel, J. L. (1978). Serendipity gas seep area, South Texas offshore. Am. Assoc. Petroleum Geologists Bull., 62, 1067-74.

Weaver, D. W. (1969). Geology of the northern Channel Islands. Pacific Sections AAPG and SEPM, Special Publications, $200 \mathrm{pp}$.

Weeks, L. G. (1965). World offshore petroleum resources. Am. Assoc. Petroleum Geologists Bull., 49, 1680-93.

Wilson, R. D., Monaghan, P. H., Osanik, A., Price, L. C. \& Rogers, M. A. (1973). Estimate of annual input of petroleum to the marine environment from natural marine seepage. Trans. Gulf Coast Assoc. Geological Societies, 23, 182-93.

Wilson, R. D., Monaghan, P. H., Osanik, A., Price, L. C. \& Rogers, M. A. (1974). Natural marine oil seepage. Science, 184, 857-65.

Wilkinson, E. R. (1971). California offshore oil and gas seeps. California Oil Fields-Summary of Operations, 57(1), 5-28.

Wong, C. S., Green, D. R. \& Cretney, W. J. (1973). Distribution and source of tar in the Pacific Ocean. Marine Pollution Bulletin, 7, 102-6.

Yerkes, R. F., Wagner, H. C. \& Yenne, K. A. (1969). Petroleum development in the region of the Santa Barbara channel. In: Geology, petroleum development, and seismicity of the Santa Barbara Channel region, California. Chapt. B, US Geol. Survey Prof. Paper 679, pp. 13-27. 